\title{
A vision for the sending of the Church in Botswana
}

\author{
Author: \\ Desmond Henry ${ }^{1}$ \\ Affiliation: \\ ${ }^{1}$ Research associate, \\ Department of Science of \\ Religion and Missiology, \\ University of Pretoria, \\ South Africa \\ Correspondence to: \\ Desmond Henry \\ Email: \\ desandlara@gmail.com \\ Postal address: \\ PO Box 37697, Faerie Glen, \\ Pretoria 0043, South Africa \\ Dates: \\ Received: 09 Sept. 2010 \\ Accepted: 17 Oct. 2011 \\ Published: 08 Dec. 2011 \\ How to cite this article: \\ Henry, D., 2011, 'A vision for \\ the sending of the Church \\ in Botswana', Verbum et \\ Ecclesia 32(1), 8 pages. \\ http://dx.doi.org/10.4102/ \\ ve.v32i1.432
}

C 2011. The Authors. Licensee: AOSIS OpenJournals. This work is licensed under the Creative Commons Attribution License.
The purpose of this article was to present a vision (of a preferred future) for the southern African ecclesia, based on an accurate understanding of what can be termed a missional ecclesiology. This concept was explored using the current context of my ministry, that of the Republic of Botswana, as a primary interlocutor.

\section{Preamble}

It is important at the outset of this article to state my context and presuppositions. Firstly, I am an African. I am a White, young male South African, working amongst the Batswana (citizens of the Republic of Botswana), who has a passion for seeing Christianity 'rooted' in Africa and seeing it grow and develop as it seeks to continue Christ's work on earth between the ages. However, having stated this, we can no longer assume that there is an 'African Christianity'; rather, there is a plurality of 'African Christianities'. Therefore, there is a need to engage with one's specific political, religious, socio-economic and geographical contexts. Secondly, over the last century, the centre of gravity in the Christian world has shifted inexorably southward, to Africa and Latin America. Today, the largest Christian communities on the planet are to be found in those regions (Jenkins 2007). Therefore, as Jenkins (2007) argues, we should be careful in making blanket statements regarding beliefs and views from a Western perspective, understanding that the largest proportion of believers lies southwards, with our views being representative of an ever-shrinking remnant of Western Christians. Lamin Sanneh (2008), a Yale University historian, asserts that Christianity is the most active frontier in the world, calling it the dawn of a 'new day' in Christian history when he righty states that African Christianity is not just an exotic, curious phenomenon in an obscure part of the world, but that African Christianity might just be the shape of things to come.

Additionally, I have to begin by acknowledging Bosch's (1991) tremendous contribution to my own missiological understanding, largely through his work entitled Transforming mission. However, as indebted as I am to Bosch for his tremendous contribution to missiology, an analysis of those sources used by Bosch in his above magnum opus disclosed that his dialogue was primarily with scholars in Europe and North America. Whilst Bosch provided some coverage of emerging thought in Africa, Asia and Latin America, it is contained mostly in his chapters on contemporary paradigms of mission. In this article, I would therefore like to engage with Bosch and voice the concerns of the emerging paradigm within an African context in order to develop a more profound African missiology.

Lastly, I am a Baptist pastor and therefore identify with the South African Baptist heritage, as well as Baptist beliefs and principles in general. I am indebted to the Baptist Union of Southern Africa for my heritage of faith and the opportunities of service provided to me over the years as a young pastor and scholar. My prayer is that this article will add great value to our union of churches as we are Christ's witnesses from Jerusalem to the ends of the earth - fulfilling the Christological, missional imperative.

\section{Introduction}

The indispensability of the Church of Jesus Christ is the primary motivation for writing this paper. We have to believe in the Church. It is all that we have got. Jesus instituted the Church to be his witness, in 'Jerusalem, Judea, Samaria and to the uttermost parts of the earth' (see Ac 1:8). An example of how our witness is to be carried out - both locally and globally - is illustrated vividly within the narrative of the Acts of the Apostles. The importance of the Acts narrative can be demonstrated in the fact that practically every 'revival' of the church's rising to its ordained mission has re-discovered the book of Acts.

As long as the Great Commission remains unfulfilled, missiological perspectives will never be out of season. Adding Afro-centric voices and concerns to the discussion should be viewed as 
an urgent undertaking of African scholarship in this milieu. The exponential growth experienced within the Christian world in the Global South adds to the importance of their perspectives. Additionally, the urgency of the imminent return of our Lord should not be disregarded easily as the Church fulfils the missio Dei. It is my belief that any constructive growth for the future success of the Church in Africa has to come from the bold recognition that if it is to succeed and partake fully in the missio Dei, 'everything must change' (see McLaren 2007:18-24). There is need for both continuity and discontinuity and, in this context, change is not negotiable. Therefore, there is a need to rediscover the essence of Jesus' intention for the Church; that is, God's redeemed people and their view of God's Kingdom with its various implications for an 'Afro-centric' missiology. There is a need for 'grassroots' missional churches, for dialogue and for unity in action. This is the overarching intention of this paper: to demonstrate the urgency of these needs by focusing on the Botswana missional context.

\section{The need and importance of a missional ecclesiology Mission transformation}

Before our discussion on the essence of biblical mission, it must be stated that missions traditionally have been viewed as Church-centred. It has, however, been observed that within the 21st century there has been a paradigmatic shift in the conceptualisation of the Christian mission. Mission today is not seen as merely an activity of the Church, for, as Guder (1998:4) states: '... Mission is the result of God's initiative, rooted in God's purposes to restore and heal creation'. Therefore, mission ultimately means 'sending with authority' (Bosch 1991:1) and although the word 'mission' never occurs within Scripture, the concept of 'sending' or 'being sent or commissioned' is a consistent biblical theme. Therefore, we can speak of God as a 'missionary God' and can understand the Church to be a commissioned people (Jn 20:21). Within the paradigm shift referred to above, we have come to understand the church's missional reorientation as a new insight into scripture, with relevant applications to churches perhaps operating under an outdated and unscriptural view of the church, rooted in traditional Western or missionary ideas about what church is and is not. This time in history will be remembered as a time of significant re-evaluation of all things 'church'. Yet, as I am about to establish, a missional ecclesiology (referring to the nature of the church as missional) is biblical, in that whatever one believes about the church needs to be anchored on what the Bible teaches. It is my firm belief that the missionary character of God is consistently and progressively revealed throughout the Old and New Testament alike. The contribution of the Old Testament is vital to understanding the New Testament's revelation and one is amiss without the witness of the New Testament to the missio Dei. The missio Dei refers to the mission of the Father, Son and Holy Spirit as revealed within history and through scripture. After all, one cannot speak about mission without recognising its Trinitarian basis.
Scripture consistently unfolds the missio Dei and, thus, we can venture to say that mission is not 'ecclesiocentric' (centred on the church) as has been historically promulgated, but, rather, mission is 'Theocentric' (centred on God).

\section{The role and importance of the church in mission today}

Whether you are a Christian living in the Global North (e.g. North America or Europe) - and are dealing with issues of postmodernity and religious pluralism - or whether you live in the Global South (e.g. Africa and South America) - and are trying to deal with the aftermath of colonialism and the disappointments of independence, democracy, development and modernity - you are sure to have one thing in common. This is a mutual understanding that, in recent days, the role and importance of the church in the world today is becoming an increasingly pertinent question for many on the global church scene. Indeed, questions such as: 'why bother with church?' or 'what programmes would serve me and my needs best?' are commonplace throughout contemporary Christendom.

Yet, whilst the Christian faith is losing ground in the Global North, scores of people are turning to Jesus Christ daily within the Global South. Christianity is here to stay in Africa! However, on a continent that has so much to offer the world, there is a real and grave danger that, in our quest to be 'worldclass' on many fronts, we may, if we are not discerning, fall into the same trap as many countries within the Global North. Against the backdrop of redundancy, extravagance, increasing Christian nominalism and the perception that the church is surreal and irrelevant to 'real life' issues (see Spong 2001), this renaissance of what can be termed missional significance is especially concerned with the importance of missions within the life of the local church (see Van Gelder 2007). This is further illustrated by the growing global voice concerning the role of the church in emerging global trends pertaining to a multiplicity of disciplines such as sociology, ecology, economics and politics. Indeed, the 'million Dollar question' is: does the church have a mission or does God's mission have a church? Or, to phrase it differently, is there a biblical basis for missions or is there a missional basis for Scripture? Missions, contrary to popular belief, do not only have a scriptural mandate, mission is rooted in the nature of God himself; missions are ultimately the missio Dei. As mentioned earlier, mission is Trinitarian in nature. This means it is God's mission, not the Church's.

What does all this mean for 'ordinary Christians' such as you and me? This truth supposes a journey of discernment between reality and the world (Van Gelder 2007), encouraging questions that pertain to reality and relate to the mission of God (missio Dei). It is a challenge to grasp the spirit of contemporary culture and baptise it in the stream of truth that flows out of God's own immersion in the world through his incarnation in the person of Jesus. The work of God must be read and interpreted along with the word of God; both are Gospel narratives and each interprets the other. 


\section{The effects of rapid change}

Over the last five decades or so we have seen a world unfold that is unlike any we could have imagined - and for which no one could have completely prepared us. Within this relatively short period of time, there have been quantum leaps in technology that constantly change the 'face' of the world. With the advent of the Internet and the growing global village, even developing economies in the Global South have felt the need to accelerate their growth to compete on a global scale. Today, we have easy access to more information, research, products and ideas than at any point in history. We have undergone what many are calling an information revolution, where we can research the most complex topic or plan an entire vacation online, including flights, hotel bookings and car hire, and still have time to sift through information regarding the best tourist hotspots to visit. The world of yesteryear seemed simpler, less complex and more predictable; the world we face today is fundamentally different. There is no denying it and, unfortunately, there's no turning back.

A few years ago, Thom Rainer and Eric Geiger (2006) wrote a book entitled, Simple church, that quickly became one of the highest bestsellers in its genre. It is a great read and has been liberating to me in my ministry. However, the question I asked myself was why has this book become so popular? The answer lies in the fact that people, regardless of whether they are from the Global North or Global South, are looking for one thing. Pastors, church leaders, missionaries and ordinary Christians (even nominal ones) are craving simplicity. Simple church; simple life. However, this can only be achieved if we take seriously the quintessence of Christianity. In other words, the intrinsic and most refined essence of living is in simple church and simple mission. Mission is the quintessence of Christianity.

Along with the accelerated global changes discussed above, many within and outside of the church are asking what Christianity's role and importance is within society. The answer to this question undoubtedly will be the great determining factor of the church's success in our age. The role of the church within society was an important consideration at the 24th General Council of the World Alliance of Reformed Churches when they met in Accra, Ghana in 2004. A statement accepted by the General Council states: 'The groaning of creation and the cries of the poor and the marginalized are calling us to conversion for and recommitment to mission' (see http://warc.jalb.de/warcajsp/news_file/doc-180-1.pdf). These are strong words that carry the connotation of complete change and total commitment to mission. However, in order for this to take place there is a need for a reinvestigation of the role and importance of the church in the world today. Mission-mindedness is no longer enough - it was never enough - there is a need for missional churches!

Sanneh (2008) states that we are currently in the middle of a major cultural shift and realignment, the implications of which are only now becoming clear. What is not always obvious to those of us in the Global South, especially in Africa, is that the 'Western' Church in Europe and North America is facing immense challenges, which, if not met head-on, will see the inevitable death of Christianity in the 'West' within the foreseeable future. These words seem quite harsh to me, as the Global North has contributed enormously to the formation and growth of Christianity within the Global South. However, there has been a clear shift in the gravity of Christianity that has seen increased growth in countries south of the equator. It has become clear that, in the near future, the Global South will overtake the growth of the Global North and that Christians in the Global South will outnumber Christians in the Global North 2.5 to 1 (Jenkins 2007). We are moving through a period of volatile, discontinuous change (Van Gelder 2007); 'our world is dominated by the extreme, the unknown, and the very improbable ...' (Taleb 2007:27).

\section{William Easum (cited in Erre 2009) pointedly states:}

We live in a time unlike any other time that any living person has known. It's not merely that things are changing. Change itself has changed, thereby changing the rules by which we live ... there is more to this change than simply a linear extrapolation of rapid change and complexity. Quantum leaps are happening that are nothing like evolution. They remove us almost totally from our previous context. Simply learning to do old chores faster or to be able to adapt old forms to more complex situations no longer produces the desired results ... running harder and harder in ministry will not work in this new world ...

(Easum, cited in Erre 2009:19)

Established churches are becoming increasingly ineffective because our past has not prepared us for ministry in the future. The discontinuity we have experienced because of these quantum leaps is comparable to the experience of the residents of East Berlin when the Berlin Wall came down: nothing in their past had prepared them for life without the Wall.

The church in Africa, although seen as one of the fastest growing communities of believers around the world, cannot immerse itself in pride, thinking that the challenges that the West are facing will not affect the spread of Christianity in Africa - despite the glowing projections. For, unless we heed the call for a reinvestigation of the essence of our faith, we will soon find ourselves in a similar situation to that of the Global North. What does tomorrow hold for Africa? Indeed, what does tomorrow hold for southern African Christianity?

The bottom line is that the church - especially in emergent Africa - inevitably has to change. Conventional Christianity, in its colonial, postcolonial and post-missionary packaging, has compromised the radical story of Jesus in favour of familiar clichés, pat answers to pressing questions and domesticated and rigid programmes that perhaps tie in with attractional church models employed as church growth mechanisms. Let us face facts: we have often not done justice to the biblical narrative in our attempts to 'do church'. Therefore, we must begin with a radical assertion that the current trends within African Christianity, although seen as 
successful in the past and present, will not suffice for future. We need to recognise the need for a new map in this new world, with which to navigate effectively and to go boldly where few have been - certainly in Africa.

Christian mission is always anchored in fidelity to the past and challenged to fidelity in the present. It must preserve, defend and proclaim the constants of the church's traditions; at the same time it must respond creatively and boldly to the contexts in which it finds itself. Christian history is, in essence, a story of the Church in mission. It is, to borrow the eloquent phrase of Harvie Conn (1984:226), a story of the encounter of Eternal Word with changing worlds. It is in the 'emerging' new world that '... society is predisposed against anything that smells of our cultural past, including Christianity and its morality' (Brantley 2005:30). This is essentially true for postcolonial Africa as well; society is predisposed to resist anything that reeks of colonial Christian forms. For this reason, many people on a global scale are engaging in a conversation about what Christianity stands for and what Church (in Africa, for Africa) can be and do (Van Gelder 2007). The conversation about the church today is undoubtedly changing: there is a contemporary rediscovery that the Gospel is indeed good news for the world (McLaren 2007). The Gospel is good news for both men and women of all races, ethnicities and nationalities - it is good news for all creation.

The realisation that this good news extends further than our own personal salvation to create a positive change in society, resonates with the contemporary conversation about the church. The Lausanne Theological working group affirmed this sentiment in the desire expressed for the outcomes of their gathering in Cape Town in 2010:

Cape Town 2010 must call Evangelicals to recognise afresh the Biblical affirmation of God's redemptive purpose for creation itself. Integral mission means discerning, proclaiming, and living out, the biblical truth that the Gospel is God's good news, through the cross and resurrection of Jesus Christ, for persons, and for society, and for creation. All three are broken and suffering because of sin; all three are included in the redeeming love and mission of God; all three must be part of the comprehensive mission of God's people. (see http://www.lausanne.org/ru/component/content/article. html?id=1194)

There is an evident need for a rediscovery of the missio Dei (see Brueggemann 2001) and the church's role within God's Kingdom in the Global North and the Global South. A discovery, I believe, that will lead to what so many are calling the Missional Church. It is my belief that this is not alien to us; it is deeply rooted in who we are as Christians, that is, followers of Christ. For whether we like it or not, a paradigm shift of epic proportions has occurred and the fact remains that those churches which continue to do things the way they have always done - without discernment - will inevitably suffer from the law of diminishing returns (see Erre 2009). The regeneration of the church in our generation is rooted in the fact that the core of Jesus' message is not only about eternity; Jesus' message also relates to personal, social and global transformation (McLaren 2007). We must prayerfully seek after new wine-skins in order to engage and 'incarnate' the Gospel to our fragmented and increasingly fractured world (see Erre 2009). After all, both the Gospel and church are inherently translatable - they are both particular, yet universal (see Van Gelder 2007). The following quotation has been most helpful to me in this regard:

One of the most important things Christians need to know about the Church is that the Church is not of ultimate importance! However, to say this is not to deny its divine origin... nevertheless, the point of the Church is not the Church itself. The Church's foundation and continued existence are not to provide refuge from a sinful world or to provide a warm and supportive community for lonely souls, or even less to be a plank of salvation on a tempestuous sea of damnation. The point of the Church is to rather point beyond itself, to be a community that preaches, serves and witnesses to the reign of God. In doing so the Church shares and continues, through the power of the Holy Spirit, the work of its Lord. So completely does the Church live for God's reign that, when it finally is fully established, the Church will be subsumed into its all-encompassing reality.

(Stuhlmueller \& Senior 1983:157)

The bottom line is: 'Only the Kingdom ... is absolute and it makes everything else relative' (Bevans \& Schroeder 2006:6).

\section{Church as quintessentially mission- orientated}

Bosch (1991:15-56) demonstrates that it is impossible to read the New Testament without taking into consideration that most of it was consciously written within a missionary context:

... in the first century, theology was not a luxury of the world-
conquering church, but was generated by the emergency
situation in which the missionizing church found itself ... mission
became the 'mother of theology'.

(Bosch 1991:489)

With time, however, theology lost its missionary dimension and within the pre-modern era, theology was seen as a whole, without any subdivisions. Theology, defined as the science of studying God and things related to God, underwent a paramount change under the influence of the Enlightenment; thus, the theology taught in many seminaries around the world can be classified easily as a child of the Enlightenment paradigm in which rationality was a pre-eminent determinant. Within the modern framework, theology was sub-divided into two entities: theory and practice. It was from this point onwards that theology evolved into the classic fourfold system seen today: Biblical Studies, Church History, Systematic Theology and Practical Theology (see Bosch 1991:489-490). Mission theology, however, has traditionally been relegated to the margins of theology and has often not been taken seriously within Christian theological circles. In many ways, this has led to its historical marginalisation, which partly is caused by the Enlightenment's distinction between 'pure' science and practical theology, where the former was seen as scientific and rational and the latter as necessary for ecclesiastical progression. 
However, by the 1960s, it was generally accepted that mission belongs to the essence of the Church. For Protestants, the Tambaram (1938) and Willengen (1952) meetings of the International Missionary Council and the New Delhi assembly of the World Council of Churches were of great significance. For Catholics, the Vatican II council of the early 1960s marked the occasion of mission's ceasing to be a prerogative of the Pope and becoming an intrinsic dimension of the worldwide Church. The resultant view was that the Church was no longer seen primarily as being over against the world but rather as being sent into the world and existing for the sake of the world. Mission was no longer merely an activity of the Church, but an expression of the very being of the Church (Bosch 1991:489-496; Van Gelder 2007:18, 19).

Thus, a missional ecclesiology will lead to a shift in the methodology of 'doing' theology and will further encourage the Church to engage society on various platforms (Hendriks 2007:1000). The church is undoubtedly a key role-player in the southern African scene, as it consistently reaches more people than any other organisation. 'It has a stronger infrastructure than even the government in connecting, serving and influencing people' (Castells 2004:303-418; Symington 2005:16165). The immense influence religious leaders exercise in southern Africa was made evident in an article that appeared in Die Burger on 16 September 2005 (Die Burger 16 September 2005:7), which, in turn, referred to a Gallup-BBC poll which reported that, across the 68 countries where the poll was conducted, the average level of trust in politicians was $13 \%$, whilst spiritual leaders received a $33 \%$ level of trust. In Africa, the level of trust reported for spiritual leaders was $74 \%$.

The premise of this paper is that the church can (and should!) play a major role in addressing the countless issues that confront southern Africans. This would call for a shift in the methodology of engaging in theology, a shift which is paradigmatic in nature and which can be described as a move from an ontological to a hermeneutical paradigm. It is my firm belief that theology is both contextual and missional by its very nature (see Van Gelder 2007:65-66) and that its task is that of holistically addressing the plethora of issues and problems faced within the region, with a multidisciplinary approach in mind (Bosch 1991:372; Hendriks 2007:1000). Makgoba (2009) is correct in stating that the church has a crucial role to play in, amongst other issues, providing an infrastructure for an African Renaissance. For, as Van Gelder (2007:54) argues: 'Ecclesia semper formanda, ecclesia semper reformanda', that is, the Church should be ever forming, the Church should be ever reforming.

Key proponents of this paradigm shift have been David Bosch, Lesslie Newbigin, the Gospel and Our Culture Network, and the Partnership for Missional Church. Their work has led to a critical engagement with the philosophical and epistemological roots of modernity and of Western theology and culture (Bosch 1991:349-363; Hendriks 2007). In light of the shift towards a hermeneutical paradigm (see Van Gelder 2007:15-21), Hendriks (2007) states:
A hermeneutical approach is more sensitive, with the understanding that our theological viewpoints are relative to our context, that theology always has a limited viewpoint and a limited grasp of wider realities. A hermeneutical approach can lead to greater humility and a greater dependence on God's grace and guidance.

(Hendriks 2007:1001)

Theology, in this new paradigm, is missional and practical in nature (see Van Gelder 2007:65-66); thus, it seeks to be contextual as the Church is not static, it is fluid and always changing - its only foundation is the grace it receives from a Triune, active God (Hendriks 2007:1002). Thus, the focus of a missional theology or ecclesiology will be on missional praxis - the church's engagement in the world. After all, one can no longer talk about the church without simultaneously talking about mission:

One can no longer talk about church and mission, only about the mission of the church, thus, a church without mission or a mission without the church are both contradictions - and where they appear, they exist only as pseudo structures'.

(Braaten 1977:55; cf. Bosch 1991:372)

Mission is not a fringe activity of a strongly established church, a pious cause that [may] be attended to when the home fires [are] brightly burning ... Missionary activity is not so much the work of the church as simply the church at work.

(Power 1970:41, 42; cf. Stransky 1982:345)

\section{Architecture for an emerging movement - Implications for Botswana and southern Africa}

There is much reflection on the many challenges and problems faced by Western churches; however, it has been my experience that very little is said about the state of the African context and the multiplicity of challenges facing African Christians. Along with this comes the affirmation that many challenges faced by 'Western Christianity' cannot be ignored; however, there is a need for African scholars to 'rediscover Christ' within their own contexts and extrapolate relevant applications from those areas. This is, in itself, an evident gap in research and is problematic because of the diversity of contexts, cultures, communities and churches within Africa. I have not found research that either acknowledges or addresses the need for a missional renaissance within the faith communities of Botswana with relevant, practical applications.

There is a need to commence with a bold recognition of the fact that the church-in-mission today is facing a world fundamentally different from anything it has faced before. Therefore, this calls for a new understanding of mission itself (Ogne \& Roehl 2008:7). For, as Bosch (1991) argues:

We live in a period of transition, on the borderline between a paradigm that no longer satisfies and one that is, to a large extent, still amorphous and opaque. A time of paradigm change is, by nature, a time of crisis ... the point where danger and opportunity meet.

(Bosch 1991:366) 
One of those opportunities for interaction between the Global North and Global South is in the ongoing conversation relating to the 'emerging Church debate'. In fact, having done some preliminary reading on the issues involved, I have become convinced that this is a global conversation regarding the same issue on different sides of the coin. McLaren $(2007: 43,44)$ discusses his intellectual journey in grappling with the concept of postmodernity - which I have always thought was largely a Western, perhaps even generational, problem. However, he states that the shift from modernity to postmodernity can be described as that '... from a hyperconfident Western culture to a culture full of second thoughts and profound suspicions' (McLaren 2007:43). Dr Mabialo Kenzo, a Congolese theologian, assisted McLaren (2007) in this journey by helping him reach the conclusion that:

\begin{abstract}
... the term Postmodern was one side of a coin that had two sides, and both sides were essential parts of one emerging global conversation ... post modernity [sic] was a key term in a conversation among the excessively confident. This concept helped ... the West to understand and undermine our own colonial culture's confidence-mania and uncertainty-phobia ... We in the West focused on the field of epistemology, which explores how we have rational confidence that what we call knowledge or truth is really, truly true ... Postcolonial [sic] was the other side of the coin, a key term in a parallel conversation among those who had been dominated and colonized by the excessively confident. The formerly colonized ... were trying to rebuild a new kind of confidence among people whose confidence had been shattered and ground into the dirt through arrogant Western colonialism. They needed a restored confidence to face the ugly aftermath of centuries of domination and exploitation. They did not focus on philosophical questions of truth and epistemology, but rather on social questions of justice, which are ultimately questions about the moral uses of power. The only way ahead ... was for the formerly [sic] colonizers and the formerly colonized to face both sides of the coin together, never wanting truth without justice or justice without truth.
\end{abstract}

(McLaren 2007:44-45)

This comparison is helpful as it places the concerns of both the Global North and Global South as important and interlinked - therefore, one cannot talk about one without giving equal consideration to the other. Also, the paradigm shift that has occurred is important for both the Global North and Global South to consider, as it is a global issue pertaining to the Christian faith and deserves the attention of the worldwide Church.

In his recent book, Churchmorph, Gibbs (2009:19-32), describes five megatrends currently impacting the Church in the West:

- a shift from modernity to postmodernity

- a shift from the Industrial Age to the Information Age

- a shift from the Christendom era to post-Christendom contexts

- a shift from production initiatives to consumer awarenesss

- a shift from religious identity to spiritual exploration.

Although Africa has been shaped by the shifts that have happened in the West, there have been significant events and trends that have shaped the context of Botswana, some of which are also true for most parts of developing Africa. In Africa, we have equally experienced change that has impacted and continues to impact Batswana society specifically:
- We have moved from colonialism to independence and postcolonialism, which continues, however, to be influenced by 'neo-colonialism' that is shaping the face of the country and the region.

- We have moved from poverty to prosperity through industry and development (Capitalism), but recognise the need for economic diversification and greater poverty reduction amongst the Batswana people.

- We have moved from missionised (through Missioninitiated churches) to Missional (African independent churches and neo-Pentecostals) as Christians in Africa realise their ultimate calling and the missio Dei.

- We have moved from the traditional era to neomodernism, where traditional values and worldviews are continuously challenged and corroded.

- We have moved from a context of underdevelopment to economic diversification in a short period of time, which perhaps has not allowed enough room for moral regeneration and may be the reason for much of the moral degradation in Batswana society.

- We have moved from mission churches, where historical ties were important to specific tribes within Botswana and where Western ideas and praxis were unquestioningly imported and thought to be correct (whether or not they were contextually relevant or effective), to spiritual churches that are independent and are largely initiated by Africans taking their context and views seriously. These independent churches focus primarily on the Holy Spirit's work in and through the life of individual Christians.

There has been much talk in recent history about the missional church and the emerging church, especially from a Western perspective. There is a growing global conversation that it is of some importance in this regard, and which poses questions such as: what is the missional church? What is the emerging church? Do these concepts have any influence over Africa? These questions may be answered by understanding more about the origins and characteristics of each of these churches, as well as the challenges they both face in today's society (Table 1).

Together, the missional church and a great extent of the emerging church represent a concern to redefine the church in post-Christendom, missional terms. Thus, they should not be regarded as conflicting, contradictory or irrelevant to North American and other Western societies - these approaches should rather be seen as complementary. It is my conviction that the missional and emerging church conversation in the West needs to be taken into consideration for an African missional ecclesiology. Much of what is represented in these dialogues, although continents apart, represents a united voice for the morphing of the church in specific contexts (see Gibbs 2009:11-19). The emerging conversation should therefore function like two sides of the same coin.

The following common characteristics of convergence between the emerging church, the missional movements and similarities in the African landscape are important for our consideration (see Gibbs 2009:41-54; Oduro et al. 2008:18-27, 40-51, 73-85, 91-103, 109-111, 126-129, 172-187, 192-201; Spong 2001:201-217): 
TABLE 1: The origins, characteristics and challenges of the missional and emerging churches.

\begin{tabular}{|c|c|c|}
\hline Description & Missional church & Emerging church \\
\hline Origins & $\begin{array}{l}\text { - Most of the coherent development that arose out of the Gospel and Our } \\
\text { Culture Network was inspired by a small group of scholars who further } \\
\text { developed the thinking of Lesslie Newbigin, whose concern was for } \\
\text { churches in Europe at the time. } \\
\text { - This church arose out of the fact that the Church in Europe, particularly, } \\
\text { had been largely discredited as the result of a lack of evidence in the lives } \\
\text { of those who claimed to be Christians. }\end{array}$ & $\begin{array}{l}\text { - This has been classified as a renewal movement rather than a missional one, } \\
\text { as the organising principle is worship and theology in a postmodern setting. } \\
\text { Some in this church say that their emerging communities are missional; } \\
\text { however, many are reactional in that they are orientated towards what } \\
\text { their community is emerging from, rather than what they are emerging to. } \\
\text { - This church can be found within historical denominations, although it } \\
\text { is represented by varying new networks and an array of independent } \\
\text { initiatives. } \\
\text { - Its major strength lies at the grassroots level at which it operates within } \\
\text { churches. }\end{array}$ \\
\hline \multirow[t]{9}{*}{ Characteristics } & - This church emphasises the formulation of a 'domestic missiology'. & $\begin{array}{l}\text { - The theory behind this church arises out of praxis and thus it tends to be } \\
\text { diverse and less coherent. }\end{array}$ \\
\hline & $\begin{array}{l}\text { - The West has become a mission field again, necessitating the placement of } \\
\text { God back into the centre of communities again and allowing him to shape } \\
\text { and give meaning to life and mission. }\end{array}$ & - This church embraces a wide range of practices and theological antecedents. \\
\hline & $\begin{array}{l}\text { - It provides a strong challenge to churches (particularly in the USA, Europe } \\
\text { and Australia) with a firm theological undergirding. }\end{array}$ & $\begin{array}{l}\text { - It is more spontaneous in nature and is a bottom-up movement, as opposed } \\
\text { to one that is a top-down, more orchestrated movement. }\end{array}$ \\
\hline & $\begin{array}{l}\text { - The concept of mission as the quintessence of the Church is the essential } \\
\text { contribution and emphasis of this movement. }\end{array}$ & $\begin{array}{l}\text { - This church represents local initiatives and strategic alliances and is thus } \\
\text { difficult to categorise. }\end{array}$ \\
\hline & - It promotes a strong focus on the 'being sent' nature of the Church. & $\begin{array}{l}\text { - It is non-confessional and is not always defined by a 'statement of faith' to } \\
\text { which all are expected to subscribe. It is typically non-denominational and } \\
\text { rather focuses on being multi-denominational. }\end{array}$ \\
\hline & $\begin{array}{l}\text { - This church focuses on the life and ministry of Jesus in and through the } \\
\text { Kingdom of God. }\end{array}$ & $\begin{array}{l}\text { - Emerging church issues are being popularised through Web-based } \\
\text { connectivity that reaches beyond denominational structures and traditions; } \\
\text { thus, it is becoming increasingly ecumenical. }\end{array}$ \\
\hline & $\begin{array}{l}\text { - It is not affiliated to any centralised institutions which could block growth } \\
\text { through control. }\end{array}$ & $\begin{array}{l}\text { - This church often can be clearer on what it does not stand for than what } \\
\text { it does stand for (i.e. it is reactionary), which has received some criticism - } \\
\text { largely from conservative circles. }\end{array}$ \\
\hline & $\begin{array}{l}\text { - In this church, communitas is viewed as superlative to community, in that } \\
\text { the most vigorous forms of community are those that come together in the } \\
\text { context of a shared ordeal or definition by a God-sized mission. }\end{array}$ & $\begin{array}{l}\text { - This church emphasises the role of Lay preachers in church life and practice } \\
\text { to represent an affirmation of the priesthood of all believers; whereas, the } \\
\text { traditional clergy's role is questioned. }\end{array}$ \\
\hline & - This church follows a deductive approach to its ministry. & - This church follows an inductive approach to its ministry. \\
\hline Challenges & $\begin{array}{l}\text { - This church struggles to translate theory into practice within the local } \\
\text { Church context and has therefore created some confusion, as missional } \\
\text { language has been adopted by pastors without any change in its modus } \\
\text { operandi. }\end{array}$ & $\begin{array}{l}\text { - This church is very diverse and - as its name implies - is still 'emerging', } \\
\text { which means that, in many ways, it is still ambiguous in nature. } \\
\text { - Mission engagement is a weak point in many 'emerging churches' and } \\
\text { appears to be clumsy and perhaps misguided at times. } \\
\text { - Eclectic spirituality in this church is predominant, which could cause a shift } \\
\text { in the focus of its ministry. }\end{array}$ \\
\hline
\end{tabular}

- an holistic, life-embracing spirituality

- regular Gospel communication

- specific outreach to de-churched and non-churched segments of the population

- the ability to demonstrate the transforming power of the Gospel

- worship that inspires mission and is inclusive of an approach that sees the whole body as necessary to participation

- a contextual worldview that is taken seriously

- an inclusive approach to services, which means all are welcome and are not seen as interruptions

- evangelisation that is an invitation to lifelong discipleship and abundant life

- a context where community (communitas) is valued

- every member ministry (EMM) is encouraged and leadership within the body welcomed

- the Bible is valued as a guide for life's journey and acknowledged as the living Word for today's world.

\section{Conclusion}

The church is indispensable; its mission is uncompromising. However, as we say in Setswana: 'Ke nako' [it is time]! It is time for Africans to reflect theologically on our (biblical) text and specific context. It is time for the acceptance of both continuity and discontinuity at local church level, as well as denominational level. Change is inevitable and everything must change in order for us to see reformation and revival in the theology and praxis of the African church. Indeed, in light of all of this, Van Gelder's (2007:54) call for constant reformation seems all the more applicable: Ecclesia semper formanda, ecclesia semper reformanda.

\section{Acknowledgements}

I wish to express my sincere thanks to my family, for allowing me the opportunity to research - thank you for your encouragement and sacrifice - and to Prof. Cornelius J.P. Niemandt, for his guidance and academic support. I also wish to thank the Faculty of Theology at the University of Pretoria, specifically the Department of Science of Religion and Missiology, for their financial assistance in the publication of this article. Without your support, my research would not be published.

\section{Competing interests}

The author declares that he has no financial or personal relationship(s) which may have inappropriately influenced him in writing this paper.

\section{References}

Anderson, A., 2007, Spreading fires, Orbis Books, Maryknoll.

Bevans, S.B. \& Schroeder, R.P., 2006, Constants in context: A theology of mission for today, Orbis Books, Maryknoll. 
Bosch, D., 1991, Transforming mission, Orbis Books, Maryknoll.

Braaten, C.E., 1977, The flaming center, Fortress Press, Philadelphia.

Brantley, M., 2005, 'The fragrance: The missional Church in c/21', Stimulus 13, 30-35 Brueggemann, W., 2001, Hope for the world, Westminster John Knox Press, London.

Castells, M., 2004, The power of identity - The information age: Economy, society and culture, 2nd edn., Blackwell, Oxford.

Conn, H.M., 1984, Eternal word and changing worlds: Theology, anthropology, and mission in trialogue, Zondervan, Grand Rapids.

'Wereldregerings steek af by SA [World governments put off by SA]', Die Burger, 16 September 2005, p. 7.

Erre, M., 2009, Death by church, Harvest House Publishers, Eugene.

Gibbs, E., 2009, Churchmorph, Baker Academic, Grand Rapids.

Guder, D.L. (ed.), 1998, Missional church: A vision for the sending of the church in North America, Eerdmans Publishing, Grand Rapids.

Hendriks, H.J., 2007, Missional theology and social development, University of Stellenbosch, Stellenbosch.

Jenkins, P., 2007, The next Christendom, Oxford University Press, New York.

Makgoba, M.W. (ed.), 1999, African renaissance, Mafube-Tafelberg, Cape Town.

McLaren, B., 2007, Everything must change, Zondervan, Grand Rapids.
Oduro, T., Pretorius, H., Nussbaum, S. \& Born, B., 2008, Mission in an African way, Christian Literature Fund, Wellington.

Ogne, S. \& Roehl, T., 2008, Transformissional coaching, B\&H Publishing Group, Nashville.

Pohlmann, M.H., 2007, Equally good news, Hebron Publishers, Randburg.

Power, J., 1970, Mission theology today, Gill \& Macmillan, Dublin.

Rainer, T. \& Geiger, E., 2006, Simple church, B\&H Publishing Group, Nashville.

Sanneh, L., 2008, Disciples of all nations: Pillars of world Christianity, Oxford University Press, New York. http://dx.doi.org/10.1093/acprof:oso/9780195189605.001.0001

Spong, J.S., 2001, A new Christianity for a new world, Harper, San Francisco.

Stransky, T.F., 1982, 'Evangelization, missions, and social action: A Roman Catholic perspective', Review and Expositor 79, 343-351.

Stuhlmueller, C. \& Senior, D., 1983, The biblical foundations for mission, Orbis Books, Maryknoll.

Symington, J. (ed.), 2005, 2005-2006 South African Christian handbook Tydskrifmaatskappy, Wellington.

Taleb, N.N., 2007, The black swan. The impact of the highly improbable, Allen Lane Publishers, London.

Van Gelder, C., 2007, The ministry of the missional church, Baker Books, Grand Rapids. 